Brit. J. industr. Med., 1953, 10, 125.

\title{
PSYCHOLOGICAL HANDICAP IN RELATION TO PRODUCTIVITY AND OCCUPATIONAL ADJUSTMENT
}

\author{
BY \\ MORRIS MARKOWE and L. E. D. BARBER \\ From the Medical Research Council Unit for Research in Occupational Adaptation
}

(RECEIVED FOR PUBLICATION JULY 5, 1952)

The clinical experience of psychiatrists suggests that neurosis, which is sufficiently severe for a person to seek treatment, and inadequate mental ability are handicaps to industrial efficiency. It is often thought by psychiatrists that persons with these handicaps fit badly into industry and produce less than the average (Tredgold, 1949 ; Curran and Guttmann, 1949), and it is a belief shared by many employers and managers. This study was made in an attempt to measure the effects on industrial efficiency of the less serious manifestations of mental ill health such as one would expect to find in ordinary groups of workers in a factory.

The assessment of mental health and industrial efficiency cannot be made with the usual precision of laboratory investigations. The number of groups within factories engaged on comparable work with uniform supervision is surprisingly limited. Moreover, only a firm prepared to lose some of its valuable production time for the future benefit of industry without promise of any direct help in its immediate problems, can be expected to cooperate. The workers themselves may be suspicious of the motives of the study, with understandably hostile attitudes towards psychologists and psychiatrists.

In a previous study of two independent groups of men and women working on conveyor belts an attempt was made to relate their productivity and effectiveness as a group to their psychological characteristics. The results were inconclusive but the experience of this work emphasized the difficulties of making such an investigation in which precise techniques cannot be used (Markowe and Barber, 1952). Nevertheless it was considered that a study should be made of a group in which both productivity and effectiveness could be assessed and related to psychological handicap for each worker. The same experimental difficulties would arise but they should be easier to overcome than in a similar study of groups.

\section{The Firm and the Group}

The factory, established for more than 50 years in a highly industrialized area, employed some 1,500 men and women and manufactured and marketed accumulators. The favourable economic position of the firm had made it relatively easy to select a stable labour force over many years. All constituent processes, which need not be described here, were carried out in the one factory. The fundamental part of an accumulator is the lead grid which when covered with lead paste forms the battery plate. The grids were made by some 80 " casters" who worked in one department. It was these men whom we chose for this study because they were the largest unselected group of workers available who were engaged on a single process under conditions allowing their productivity to be measured. They were suitable for other reasons, for they differed in their efficiency and experience and their work was continuous over long periods. The study was made between June and December, 1949.

The grid-casters use hand-operated, gas-heated moulds into which they ladle molten metal (mainly lead) from a heated reservoir. After momentary cooling of the mould, they extract the grid plate (or casting) with pincers. Another group of workers impregnate these plates with lead paste and they are subsequently embodied in an accumulator.

The shop is run continuously from 6 a.m. on Monday to 6 a.m. on Saturday in three shifts. The workers change shifts at weekly intervals. The 
four charge-hands work on a different shift system from the workers, who thus have constantly changing supervision. The men are paid individually according to the number of grids they produce. Wages are based on a system of payment determined by work-study ; there are no restraints upon possible output other than self-imposed ones.

New employees are examined medically to exclude those who might be harmed by the process, particularly by exposure to lead. All are over 21 years of age and women are not employed. The ages of the men ranged from 22 to 64 years with a median of 37. The distribution of experience in the moulding department was not continuous and could be broken into three groups; less than 5 years, 33 men, 5-17 years, 18 men, more than 18 years, 29 men. All but one of the workers were married. They were seldom absent from work. Only 17 men were absent more than twice in 1949 and a quarter of the group accounted for four-fifths of the total days lost. The group could not be regarded as a random collection of workers since various selective processes had been operating in its formation over many years, but such processes operate in any similar group of piece workers and it can be reasonably regarded as representative of a group of men employed in light industry.

\section{Methods of Study}

Psychological handicap, which is an inexact term, was assessed on two criteria :-

Poor Recent Mental Health.-This was defined as a history of definite disabling psychological illness requiring treatment within the last 12 months, or a history of psychological ill-health evident to the patient or to an observer, but not incapacitating or needing treatment.

Low General Mental Ability.-This was defined as that performance in the Dominoes Test which locates the individual amongst the lowest $10 \%$ of the group studied, and would (subject to allowance for age) locate him among the lowest $15 \%$ of the general adult population.

Data on height, weight, visual acuity, and haemoglobin estimations were taken from the records of the factory medical department. Special tests of overall muscular strength, static effort tolerance, and Schneider cardiovascular efficiency were made by the medical investigator. Each worker's life history was examined from a psychiatric standpoint, with particular reference to the time of the interview and the previous 12 months. Recent mental and physical health were rated on a four-point scale.
Mental health was deemed to range from rating 1 (healthy, mature, and vigorous) to rating 4 (definite disabling sickness requiring treatment); rating 2 covered the rest of the "normal" range, while rating 3 included minor states of ill health, which either did not incapacitate the worker or oblige him to seek treatment. There was a similar range for physical health.

Personality was rated for 13 traits on three-point scales. Twelve were rated as paired opposites as tollows : expansive, reticent ; ascendant, submissive ; objective, subjective ; flexible, rigid ; persistent, irresolute ; equable, labile ; emotionally broad, narrow ; emotionally strong, weak ; intelligent, unintelligent ; interested in people, interested in things; conscientious, irresponsible; mature, immature. Obsessional traits were also recorded, and ranged from absent or minimal to marked and interfering with work or leisure.

A large number of psychological tests were administered. Full details of these are reported elsewhere (Heron, 1952; 1953).

In a separate interview each man was asked for details about his home and his working experience, such as his family obligations, occupational history, housing, time and cost of travelling, and his present job, but questions about rent and wages were not asked.

Each man's adjustment to his work was judged by his absences from work and accidents and the opinion of his supervisors. The actual criteria employed were :-(1) Total number of absences from work irrespective of cause or duration during the calendar year 1949 (holidays excepted); (2) total number of days absent from work irrespective of cause during the same period ; (3) total number of accidents as reported to the ambulance room during the same period; (4) the rating, on a fivepoint scale, of adjustment to the demands of job situation, obtained by combining the ratings made on each man by six supervisors on each of two occasions five weeks apart. These supervisors included the four charge-hands previously mentioned (Heron, 1952b).

An index of the production of common starter grids was calculated for 45 of the 80 men in the group. It was based on a period of six months and only intact shifts were used, in order to exclude production of other types. This index was compared with the firm's indices which had been calculated for the same 45 men during the same period but had included all types of grid which they had been producing. The statistical comparison gave reasonable grounds tor taking a modified personal performance index calculated from the firm's 
records as a measure of productivity for all 80 men studied. This was accordingly computed for a 67-week period from September, 1948, to December, 1949 (Heron, 1952b).

\section{Findings}

As a group these workers were accepted as the most important and best paid in the factory and acknowledged as the élite of the labour force. In consequence they had been sifted and tested by both management, supervisors, and each other, resulting in a concentration of characteristics which were quite striking clinically and hardly to be expected in the general population.

From the standpoint of recent mental health some $4 \%$ were deemed to be suffering from definite disabling sickness requiring treatment, and a further $21 \%$ were considered to be in minor states of ill health below the normal range. These unsatisfactory states were varied and comprised anxiety neuroses, mild obsessional disorder, cardiac neurosis, and cerebral arteriosclerosis. It must be recalled that these men were members of a normal.working group, and not patients attending a clinic, and they showed a very low rate of absence. Most of the men were expansive, flexible, persistent, extraverted, mature personalities, and devoid of marked obsessional traits. Their intelligence covered a wide range but the average was lower than that found in soldiers between the ages of 18 and 21 years examined while on National Service by the same test at the time this study was being made.

To make comparisons possible, productivity and general mental ability scores were divided into nine grades, which were normalized percentile scores : grade 1 was the highest and 9 the lowest. In the supervisors' ratings of job adjustment, rating 1 was good and 5 was poor; in recent mental health rating 1 was good and 4 was poor. The group will now be considered comparing the highest and lowest grades or ratings for various characteristics.

Industrial Criteria.-When the workers were divided into groups according to their industrial performance, no clear medical and psychological characteristics emerged to account for their differing work records. Their personality and health, however, showed some relationship to output and adjustment in the less satisfactory groups.

Table 1, dealing with the highest and lowest producers, reveals that experience in the department was equally extensive in both, that recent mental health was mainly within normal limits in both, that general mental ability showed no appreciable difference, and that in general the supervisor's
TABLE 1

HIGHEST AND LOWEST PRODUCERS

\begin{tabular}{|c|c|c|c|c|c|c|c|}
\hline & $\begin{array}{l}\text { Code } \\
\text { No. }\end{array}$ & Age & $\begin{array}{c}\text { Experi- } \\
\text { ence } \\
\text { in } \mathbf{M} \\
\text { Depart- } \\
\text { ment } \\
\text { (years) }\end{array}$ & $\begin{array}{l}\text { Recent } \\
\text { Mental } \\
\text { Health }\end{array}$ & $\begin{array}{l}\text { General } \\
\text { Mental } \\
\text { Ability }\end{array}$ & $\begin{array}{l}\text { Obses- } \\
\text { sional } \\
\text { Rating }\end{array}$ & $\begin{array}{c}\text { Super- } \\
\text { visor's } \\
\text { Rating } \\
\text { on Job } \\
\text { Adjust- } \\
\text { ment }\end{array}$ \\
\hline 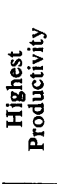 & $\begin{array}{l}20 \\
24 \\
25 \\
35 \\
37 \\
40 \\
55 \\
75\end{array}$ & $\begin{array}{l}32 \\
35 \\
36 \\
42 \\
29 \\
25 \\
31 \\
50\end{array}$ & $\begin{array}{r}2 \\
10 \\
13 \\
21 \\
3 \\
2 \\
3 \\
27\end{array}$ & $\begin{array}{l}2^{*} \\
2 \\
1 \\
1 \\
2 \\
3 \\
2 \\
2\end{array}$ & $\begin{array}{l}7 \\
2 \\
7 \\
6 \\
5 \\
2 \\
3 \\
8\end{array}$ & $\begin{array}{l}2 \\
2 \\
2 \\
1 \\
1 \\
2 \\
3 \\
3\end{array}$ & $\begin{array}{l}3 \\
1 \\
2 \\
2 \\
2 \\
3 \\
2 \\
1\end{array}$ \\
\hline 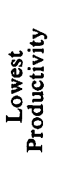 & $\begin{array}{l}1 \\
28 \\
38 \\
58 \\
62 \\
65 \\
66 \\
67\end{array}$ & $\begin{array}{l}29 \\
30 \\
27 \\
41 \\
34 \\
53 \\
52 \\
41\end{array}$ & $\begin{array}{c}3 \\
2 \\
3 \\
25 \\
\text { mths. } \\
24 \\
25 \\
7\end{array}$ & $\begin{array}{l}2 \\
2 \\
3 \\
2 \\
2 \\
2 \\
2 \\
1\end{array}$ & $\begin{array}{l}3 \\
7 \\
5 \\
9 \\
5 \\
8 \\
5 \\
4\end{array}$ & $\begin{array}{l}2 \\
2 \\
1 \\
2 \\
3 \\
1 \\
1 \\
1\end{array}$ & $\begin{array}{l}3 \\
3 \\
4 \\
5 \\
5 \\
5 \\
3 \\
3 \\
3\end{array}$ \\
\hline
\end{tabular}

* For explanation of ratings see above.

ratings of job adjustment were lower for the lowest producers.

The Highest Producers.-Among the highest producers it is interesting to observe three men, Nos. 24, 75, and 20. The first two had the highest rating from the supervisors for job adjustment, No. 20 had an average rating for job adjustment. No. 24 was a man of high intelligence with strong motivating interests of pride and perfection at work, and at home ambitions for his house and for farming. He made frequent heavy bets and was almost a professional punter. Happy and contented, introverted and asocial, he worked at a steady rhythm, without monotony or exhaustion but with some day dreaming. No. .75, a highly obsessional worker who suffered from a duodenal ulcer and early arteriosclerosis, will be discussed later on in the section dealing with men of low intelligence.

No. 20 was brought up by an excitable widowed mother in a family of six ; his father was killed in 1918 when the subject was one year old, and he lost two brothers on active service. After many changes of job he volunteered for the Army, served abroad, and spent two years as a lance-corporal in Italy where he married a local girl. Since returning home he had raised a family of two, and was buying his own house; he had no circle of relatives or friends. He was shy and effeminate with subnormal general mental ability, very few interests or drives, timid and moderately meticulous. He did not consider the shift system unduly strenuous, and maintained a constant average performance at work, enjoying good health. His high productivity 
might be related to the financial demands of a growing family and of buying a house.

The Lowest Producers.-Recent mental health ratings show the majority of the lowest producers to be within normal limits, only one being subnormal (No. 38). He suffered from moderate anxiety with frequent headaches, lassitude, irritability, and excessive fatigue; he was vaguely ambitious, reticent and poorly integrated, and of average intelligence for the group. He showed poor effort tolerance (Schneider Index 8) and was asocial.

The social background often provides a suggestive explanation for the low production in this group. Some had wage-earning children at home. One man had a highly organized and lucrative domestic occupation (a pig and poultry farm) shared with his father and two fellow shift-workers. He stated that he did not work "all out" at grid-casting, but reserved his energies for family and spare-time farming. He was preoccupied with his farm and was ambitious to own and to be occupied wholly with a small business. He was indeed a satisfied and happy man.

In Table 2 we show the mental state of men in the group consisting of those who obtained both a productivity grading of 6 or worse and a supervisory rating of 4 or 5 , i.e. the $2 \%$ who were least effective industrially. They were introverted, of rather low intelligence, without ambition and with a history of trequent changes of job. But at least two were in fact ambitious and anxious to progress; they were extraverted, vigorous, and hypomanic individuals who were a source of trouble to their supervisors. One of these was a new worker,

TABLE 2

MENTAL STATE OF LEAST INDUSTRIALLY EFFECTIVE MEN

\begin{tabular}{c|c|c|c|c|c}
\hline & Code & $\begin{array}{c}\text { Experi- } \\
\text { ence in } \\
\text { Moulding } \\
\text { Depart- } \\
\text { ment } \\
\text { (years) }\end{array}$ & $\begin{array}{c}\text { Recent } \\
\text { Mental } \\
\text { Health }\end{array}$ & $\begin{array}{c}\text { General } \\
\text { Mental } \\
\text { Ability }\end{array}$ & $\begin{array}{c}\text { Obses- } \\
\text { sional } \\
\text { Rating }\end{array}$ \\
\hline 5 & 30 & 2 & $2 *$ & 5 & 1 \\
38 & 27 & 3 & 3 & 5 & 1 \\
44 & 37 & 2 & 1 & 4 & 1 \\
47 & 24 & mths. & 1 & 4 & 2 \\
58 & 41 & 28 & 2 & 9 & 2 \\
62 & 34 & mths. & 2 & 5 & 3 \\
70 & 33 & mths. & 2 & 8 & 2 \\
79 & 44 & 17 & 1 & 7 & 2 \\
\hline
\end{tabular}

* For explanation of ratings see p. 127.

recently married and living with his wife's parents. His wife was earning, and he had many friends. The other man was an experienced worker. He was energetic and sociable, but harried by a menopausal wife who was preoccupied by children, sex, and health. Both men had numerous outside interests, were well integrated and moderately obsessional in temperament, and were rated as having very good mental health.

Absence from Work.-In Table 3 we give the ratings and grades for industrial effectiveness and

TABLE 3

ANALYSIS OF LEAST RELIABLE ATTENDERS

\begin{tabular}{c|c|c|c|c|c|c|c}
\hline $\begin{array}{c}\text { Code } \\
\text { No. }\end{array}$ & Age & $\begin{array}{c}\text { Experi- } \\
\text { ence } \\
\text { in M } \\
\text { Depart- } \\
\text { ment } \\
\text { (years) }\end{array}$ & $\begin{array}{c}\text { Recent } \\
\text { Mental } \\
\text { Health }\end{array}$ & $\begin{array}{c}\text { General } \\
\text { Mental } \\
\text { Ability }\end{array}$ & $\begin{array}{c}\text { Obses- } \\
\text { sional } \\
\text { Rating }\end{array}$ & $\begin{array}{c}\text { Super- } \\
\text { Produc- } \\
\text { tivity }\end{array}$ & $\begin{array}{c}\text { visor's } \\
\text { Rating } \\
\text { on Job } \\
\text { Adjust- } \\
\text { ment }\end{array}$ \\
\hline 1 & 29 & 3 & $2 *$ & 3 & 2 & 8 & 3 \\
2 & 24 & 2 & 3 & 4 & 2 & 4 & 4 \\
15 & 37 & 8 & 2 & 6 & 1 & 5 & 3 \\
20 & 32 & 2 & 2 & 7 & 2 & 2 & 3 \\
38 & 27 & 3 & 3 & 5 & 1 & 8 & 4 \\
43 & 48 & 25 & 2 & 5 & 1 & 6 & 2 \\
46 & 50 & 25 & 3 & 4 & 3 & 5 & 1 \\
47 & 24 & 1 & 1 & 4 & 2 & 6 & 5 \\
66 & 52 & 25 & 2 & 5 & 1 & 9 & 3 \\
80 & 29 & 2 & 3 & 3 & 1 & 3 & 3 \\
\hline
\end{tabular}

* For explanation of ratings see p. 127.

mental state of a group of men who were absent during the year both on more than three occasions and for a total of nine days or more, i.e., the $12 \%$ least reliable in attendance. Four of these men had a poor record of recent mental health. Three were under 30, well below the median age of the gridcasters.

In this group five of the men who are below 30 years of age account for three-fifths of the absence though only for two-fifths of the total number of days lost during 1949. In other words, these younger men seem to like taking time off frequently but do not stay away for long. The picture for the older men is the reverse. Seven of the 10 served in the last war, and while medical and psychological problems of readjustment may partly explain their high absenteeism, domestic and socioeconomic reasons must also be taken into account.

The Worst in Mental Health.-Turning to the extremes of recent mental health, in Table 4 we find that of those with the poorest rating in mental health the clinical findings are varied and include three men with marked obsessional features.

Productivity indices were again mainly about the average for all grid-casters ; only one (No. 42) was significantly below the mode. This man was timid, effeminate, and introverted and was suffering from a mild anxiety state. Since taking on the commitments of a new house his wife had worked to increase the family income. He was the youngest of this subgroup and his experience was relatively low ; his introversion might well explain his fair 
TABLE 4

EXPERIENCE, PRODUCTIVITY, AND JOB ADJUSTMENT OF MEN WITH BEST AND WORST RECENT MENTAL HEALTH RATINGS

\begin{tabular}{|c|c|c|c|c|c|}
\hline & $\begin{array}{l}\text { Code } \\
\text { No. }\end{array}$ & Age & $\begin{array}{c}\text { Experience } \\
\text { in M } \\
\text { Department } \\
\text { (years) }\end{array}$ & Productivity & $\begin{array}{c}\text { Supervisor's } \\
\text { Rating } \\
\text { on Job } \\
\text { Adjustment }\end{array}$ \\
\hline $\overrightarrow{\mathscr{\sharp}}$ & $\begin{array}{l}03 \\
09 \\
10 \\
11 \\
21 \\
25 \\
26 \\
27 \\
30 \\
32 \\
35 \\
36 \\
39 \\
44 \\
47 \\
48 \\
59 \\
60 \\
61 \\
64 \\
67 \\
68 \\
69 \\
74\end{array}$ & $\begin{array}{l}33 \\
47 \\
52 \\
31 \\
37 \\
36 \\
49 \\
51 \\
28 \\
36 \\
42 \\
36 \\
32 \\
37 \\
24 \\
48 \\
52 \\
45 \\
43 \\
34 \\
41 \\
53 \\
38 \\
42\end{array}$ & $\begin{array}{c}1 \\
27 \\
25 \\
1 \\
2 \\
13 \\
23 \\
25 \\
3 \\
9 \\
21 \\
1 \\
2 \\
2 \\
\text { Mths. } \\
22 \\
17 \\
23 \\
25 \\
\text { mths. } \\
6 \\
24 \\
\text { mths. } \\
21\end{array}$ & $\begin{array}{l}5 \\
6 \\
5 \\
7 \\
5 \\
2 \\
7 \\
7 \\
5 \\
3 \\
2 \\
4 \\
3 \\
6 \\
6 \\
4 \\
7 \\
6 \\
3 \\
6 \\
8 \\
7 \\
4 \\
4\end{array}$ & $\begin{array}{l}3 \\
3 \\
3 \\
3 \\
5 \\
2 \\
2 \\
2 \\
3 \\
3 \\
2 \\
4 \\
3 \\
4 \\
5 \\
2 \\
3 \\
1 \\
3 \\
3 \\
3 \\
1 \\
4 \\
4\end{array}$ \\
\hline $\begin{array}{l}\vec{\omega} \\
\text { bे } \\
\dot{3}\end{array}$ & $\begin{array}{r}6 \\
13 \\
16 \\
42 \\
45 \\
46 \\
54 \\
73\end{array}$ & $\begin{array}{l}40 \\
35 \\
37 \\
33 \\
64 \\
50 \\
41 \\
46\end{array}$ & $\begin{array}{r}12 \\
9 \\
13 \\
12 \\
26 \\
25 \\
9 \\
24\end{array}$ & $\begin{array}{l}5 \\
4 \\
6 \\
7 \\
5 \\
5 \\
3 \\
5\end{array}$ & $\begin{array}{l}3 \\
5 \\
3 \\
2 \\
3 \\
1 \\
2 \\
2\end{array}$ \\
\hline
\end{tabular}

For full explanation of ratings see p. 126 .

Highest $=$ rating 1 ; Lowest $=$ rating 4 .

adjustment rating by the supervisors, since he would tend to keep to himself and his work.

The outstanding findings in this group are again the average range of productivity together with average or fair adjustment to the job as rated by supervisors with the exception mentioned above.

The Best in Mental Health.-Of the men with the best gradings in recent mental health, the mean age was high (40 years), experience was with few exceptions high, productivity was slightly below average, while supervisors' ratings tended to be good (probably because of longer service).

The Lowest in Intelligence.--Of the six men with the lowest intelligence (an I.Q. of 82 or less, corresponding to the lowest $15 \%$ of adult men in the general population) with one notable exception (No. 75 ) all were in the lower $50 \%$ of producers. This was unexpected in so far as all but one had over 20 years' experience, forming a sharp contrast with the experience of the most intelligent group (Table 5). As mentioned previously No. 75 was a highly obsessional individual and in the top group for production and for job adjustment ; he was most energetic and meticulous, extraverted, had many
TABLE 5

AGE, EXPERIENCE, PRODUCTIVITY, AND JOB ADJUSTMENT RATINGS OF MEN WITH HIGHEST AND LOWEST GENERAL MENTAL ABILITY GRADES IN GROUP OF 80 WORKERS

\begin{tabular}{|c|c|c|c|c|c|}
\hline & $\begin{array}{l}\text { Code } \\
\text { No. }\end{array}$ & $\underset{\text { (years) }}{\text { Age }}$ & $\begin{array}{c}\text { Experience } \\
\text { in } \mathbf{M} \\
\text { Depart- } \\
\text { ment } \\
\text { (years) }\end{array}$ & $\begin{array}{c}\text { Produc- } \\
\text { tivity }\end{array}$ & $\begin{array}{c}\text { Super- } \\
\text { visor's } \\
\text { Rating } \\
\text { for Job } \\
\text { Adjust- } \\
\text { ment }\end{array}$ \\
\hline 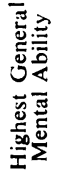 & $\begin{array}{l}11 \\
13 \\
24 \\
40 \\
42 \\
74 \\
78\end{array}$ & $\begin{array}{l}31 \\
35 \\
35 \\
25 \\
32 \\
42 \\
31\end{array}$ & $\begin{array}{r}1 \\
9 \\
10 \\
2 \\
11 \\
16 \\
1\end{array}$ & $\begin{array}{l}7 \\
4 \\
1 \\
2 \\
7 \\
4 \\
4\end{array}$ & $\begin{array}{l}3 \\
5 \\
1 \\
3 \\
2 \\
4 \\
4\end{array}$ \\
\hline 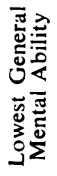 & $\begin{array}{l}17 \\
58 \\
60 \\
65 \\
70 \\
75\end{array}$ & $\begin{array}{l}43 \\
41 \\
45 \\
53 \\
33 \\
50\end{array}$ & $\begin{array}{c}21 \\
25 \\
23 \\
23 \\
\text { Mths. } \\
27\end{array}$ & $\begin{array}{l}5 \\
9 \\
6 \\
8 \\
7 \\
1\end{array}$ & $\begin{array}{l}4 \\
5 \\
1 \\
3 \\
4 \\
1\end{array}$ \\
\hline
\end{tabular}

For explanation of ratings see p. 126.

friends, and spent his spare time as a hairdresser. He suffered from a duodenal ulcer as well as hypertension. No. 58 was an expansive, dominant, and moderately obsessional man who had always wished to become a trapeze artist. He was a fresh and healthy-looking pyknic, happy, contented, and sociable with excellent recent mental health, and a wife and son who both worked and so contributed to the family income.

In Table 6 we give the data of men in the group consisting of those who obtained a mental health

TABLE 6

RATINGS OF MEN DOUBLY HANDICAPPED PSYCHOLOGICALLY

\begin{tabular}{c|c|c|c|c|c}
\hline $\begin{array}{c}\text { Code } \\
\text { No. }\end{array}$ & $\begin{array}{c}\text { Age } \\
\text { (years) }\end{array}$ & $\begin{array}{c}\text { Experi- } \\
\text { ence } \\
\text { in M } \\
\text { Depart- } \\
\text { ment } \\
\text { (years) }\end{array}$ & $\begin{array}{c}\text { Obses- } \\
\text { sional } \\
\text { Rating }\end{array}$ & $\begin{array}{c}\text { Produc- } \\
\text { tivity }\end{array}$ & $\begin{array}{c}\text { Super- } \\
\text { visor's } \\
\text { Rating } \\
\text { for Job } \\
\text { Adjust- } \\
\text { ment }\end{array}$ \\
\hdashline 6 & -40 & 12 & 3 & -7 & 3 \\
12 & 27 & 2 & 1 & 4 & 3 \\
14 & 43 & 25 & 1 & 7 & 2 \\
17 & 43 & 21 & 1 & 5 & 4 \\
33 & 44 & 25 & 2 & 5 & 2 \\
45 & 64 & 26 & 1 & 5 & 3 \\
63 & 58 & 29 & 1 & 7 & 1 \\
73 & 46 & 24 & 2 & 5 & 2 \\
\hline
\end{tabular}

For explanation of ratings see p. 126

rating of 3 or 4 and also a general mental ability grade of 6 or worse. They were the men who were doubly handicapped psychologically. They had an average output, and in every case but one were rated by the supervisors as reasonably well adjusted to their job. 
One of these (No. 14) suffered from a chronic anxiety state with marked somatic complaints; he worried a great deal and was of a labile temperament. Although a garrulous extravert he had no special friends at work yet represented the group on the Works Committee. He had considerable interests in the Church and many friends, but no recreations beyond his home with three children at school. His wife augmented the family income by working. Another (No. 63) suffered from reactive depression particularly on night duty, was arteriosclerotic and also one of the oldest workers in the department. As well as finding the work fatiguing, especially on nights, he was slow and tremulous. His family commitments were now minimal, with two adult and independent sons earning good wages. These facts, together with the low general mental ability of these two men, would explain their subnormal productivity.

\section{Discussion}

For the whole group there was no apparent association between productivity and psychological handicap, but at the extreme ends of the scale intelligence showed a relationship with productivity. Thus the most intelligent men produced slightly more than the average for the group, while the least intelligent were among the poorer producers. But the latter were by no means men with poor mental health. Social influences operating outside the factory played a larger part, it appeared, in determining output than mental health. Men whose income was supplemented by children at work or by a domestic occupation, such as keeping poultry, produced less grids than the average.

The conditions under which the men were working may explain the general lack of association between productivity and psychological handicap for the whole group. Although the management did everything to encourage high output, there were forces of public opinion among the workers which tended to settle what should be " average " earnings and therefore productivity. There were fears that high production might "use up" the work and result in short time, especially in this factory where, as many of the grid casters remember, seasonal working was the practice before 1938. Productivity therefore has an artificial ceiling imposed by the workers themselves, and is dependent on external social and domestic demands. The effect of this internal control on productivity cannot be ignored in any attempt to utilize such measures for purposes of research. It should be noted also that earnings were considerably above national averages and varied between $£ 9$ and $£ 11$ per week with regular and constant employment.
There is no difficulty in understanding why the most favourable ratings on " job-adjustment " were given to more experienced workers. It is less easy to see why the men who were given unsatisfactory ratings did not include most of those with neurotic disabilities. It is possible that in a much larger group, including more workers with pronounced neurotic traits such as hypochondriasis, paranoid attitude, insecurity, and gross morbid anxiety, the findings would have been very different. This would also apply to absence from work.

Although domestic and social factors would usually be prominent in causing absence, the small number of persons with poor recent mental health makes it unsafe to draw a conclusion from the fact that recent mental health ratings were, in the most absent group, normal or only slightly below normal. This may in part be explained by the fact that this was a particularly normal group in which the majority of the workers were of long standing. Such a group is the result of active and continuous selection by management, supervisors, and the workers themselves. Thus the assumption that workers who have a psychological handicap such as neurosis often fit badly into industry and produce less than the average worker was not confirmed in this limited study of 80 workers. There was evidence that productivity was affected to a slight extent by general mental ability, the most intelligent producing more than the average, while the least intelligent were among the poorer producers.

\section{Summary}

A group of 80 male lead grid casters was studied in an attempt to measure the effect of psychological handicap upon industrial efficiency.

The group of workers were between 22 and 64 years old, with a median age of 37 , and had experience of the work varying from a few months to more than 25 years.

The group covered a wide range of intelligence, but the average was lower than that found in a comparable group of soldiers aged 18 to 21 examined by the same test.

Of the two groups of the highest and lowest producers, no great differences in experience or general mental ability were discernible, and the recent mental health of both groups was within normal limits.

The men were grouped into the best and the worst in mental health. With one exception it was found that in the group assessed as worst in mental health the range of productivity was normal with average or fair adjustment to the job. For the best in mental health productivity was slightly below 
average but supervisors' ratings tended to be good.

It is suggested that neither psychological handicap nor mental ability affected productivity in all groups so much as social backgrounds in the home and in the factory. Public opinion among the workers tended to settle what should be " average " earnings, and therefore productivity, based on fears of the work being " used up", resulting in short time in what was a seasonal occupation before 1928 .

The smallness and the selection of the group studied made it impossible to regard the findings relating to job-adjustment and to absence with confidence. The group was an élite composed by continuous selection and included few persons with poor recent mental health.

The assumption that workers who have a psychological handicap such as neurosis produce less than the average worker was not confirmed in this limited study of 80 workers. Productivity was slightly affected by general mental ability, the most intelligent producing more than average and the least intelligent being among the poorer producers. Men rated low both for mental health and general ability had an average output and were rated as reasonably well adjusted to the job.

We gratefully acknowledge our indebtedness to Professor Aubrey Lewis, Hon. Director of the M. R. C. Unit, and to our colleagues, Dr. Alastair Heron and Mr. Peter Venables, for assistance, Without the constant help of Professor Ronald E. Lane and Dr. Dennis Malcolm this project could not have been completed.

\section{REFERENCES}

Curran, D., and Guttmann, E. (1949). Psychological Medicine (3rd edition), Livingstone, Edinburgh.

Heron, Alastair (1952a). J. appl. Psychol., 36, 385.

(1952b). Occup. Psychol., 26, 78.

(1953). To appear in J. soc. Psychol.

Markowe, M., and Barber, L. E. D. (1952). British Journal of Industrial Medicine, 9, 221.

Tredgold, R. F. (1949). Human Relations in Modern Industry, Duckworth, London. 